\title{
The Methods for Creation of the Original Sunflower Material
}

\author{
Aksyonov IV* and Amelin AV \\ Orlovskiy State Agrarian University, Russia
}

Submission: February 23, 2017; Published: February 27, 2017

*Corresponding author: Aksyonov IV, Orlovskiy State Agrarian University, Oryol, Russia, Email: aksyonov-igor@rambler.ru

\section{Opinion}

In Rossiya, the sunflower is the main oilseed crop. In the market of oilseed sunflower is essential and among the most profitable crop, providing a receipt, subject to the growing technology, efficiency above $80 \%$. The market of sunflower oil in Rossiya is characterized by an increase in production of sunflower oil, a significant increase in its exports and reducing imports. This has allowed Rossiya to take the leading position in the world in the export of sunflower oil.

Increasing the productivity of sunflower based on improving the genetic potential of the newly created self-pollinated parent lines and their hybrid combinations, science-based cultivation technologies, high-quality preparation of seed material with high sowing and varietal characteristics. One of the main indicators of the attractiveness and the economic feasibility of the production of varieties and hybrids of sunflower is the level of implementation of the genetic potential of varieties and hybrids adapted to the growing conditions, due to the use of agricultural enterprises of the appropriate level of technological cultivation.

Assessing opportunities sunflower cultivation within the modern technology demonstrates the need to create a new source material with a high level of genetic productivity and tolerance to major originators of cultural disease that will ensure the effectiveness of diversification areas of cultivation and use of sunflower raw material in conditions of not only the steppe and forest-steppe of Ukraine, but also in the northern part of the country with less heat resources during the growing season.

Foridentification of the newly created high-yielding of original materials used in traditional breeding plant morphological signs. However, morphological signs can be complex nature of inheritance, may depend on the environmental conditions. The selection of plants only morphological characters may be incorrect and does not contribute to the production of the raw material with high genetic purity and productivity. This is due to the fact that different morpho types in some cases are the result of one and the same mutation, and conversely, equal morpho types, in some cases, the changes are the result of different genes.

During the evaluation and selection of plants at the molecular level using as allelic variants systematizing characteristic components electrophoretic spectra of proteins where the main components of the protein fraction $11 \mathrm{~S}$ globulins are allowed to identify the gene locus electrophore grams proteins and create a new feed. Studied and created sunflower lines differed by the presence-absence of the protein components in the spectra electrophore grams: $1 \mathrm{Hel}, \mathrm{Hel}$ 2, $3 \mathrm{Hel}, \mathrm{Hel}$ 4, $5 \mathrm{Hel}$, Hel 6.

Alleles of the genes controlling the synthesis of a polypeptide shown in electrophore grams separate strips. Analysis of electrophoretic spectra revealed that helianthinin genetic control is performed at least 5-6 loci (1 Hel, Hel 2, $3 \mathrm{Hel}$, Hel 4, Hel 5, Hel 6). Have all created lines always noted on electrophore grams presence geliantininkodiruyuschih locuses - Hel 1, $2 \mathrm{Hel}$, Hel 3, 4 Hel, Hel 6. The locus 5, presented by one component, it is observed only in individual sunflower samples.

The method of selection for protein spectra obtained from inter specific hybrids created self-pollinated parent lines OR338V OR106V and sunflower, which do not differ in morphology, but have differences on the molecular level with the different manifestations of quantitative traits. Selected for the protein spectrum, during the creation of the parent line OR3-38V, inbred line 0R106V has a shorter duration of 14 days of the growing season, and belongs to the third group of ripeness.

Parent line GE3-38V period has a duration of 114 days, it refers to the fifth group of maturity, characterized by a lower 2.8 g weight of 1000 seeds and is able to generate higher yields of 1.9t/hectare. Hybrid combinations of germline 0R3-38V with sterile maternal lines OR2A, OR5A form and productivity within 4.0-5.0 t/hectare. The level of the yield of hybrid combinations 
of germline OR106V with sterile maternal lines OR2A is within 3.0-3.5 $\mathrm{t} /$ hectare at the same level of fat content in the seeds of 46.0-46.2\%.

Research has shown that when creating the source material and determining the productivity of the parental forms sunflower revealed the relationship between the increase in seed weight baskets and decreasing soil moisture sunflower plants, the costs per unit of NPP (net productivity of photosynthesis) on the fifth stage of organogenesis of sunflower plants. Between these parameters set a negative correlation. The correlation coefficient, depending on the maternal and paternal created form is in the range $r=-0.80-1.00$.

The consumption rate of soil moisture per unit of NPP $\left(\mathrm{m}^{3} / \mathrm{g} /\right.$ $\mathrm{m}^{2}$ per day), as a biological entity coefficient can simultaneously determine the most economical consumption of moisture genotypes in the crucial period of formation of generative organs (the phase of budding and the beginning of the formation of baskets) and shows the extent of the relation, in which the unit consumption of soil moisture per unit of NPP plant ensures the formation of seed weight in sunflower head.

This relationship is the basis for the method of identification and selection of samples of sunflower on high productivity in the process of creating the raw material, the donor high productivity varieties. It is found that the minimum soil moisture flow rate per unit NPP possibility objectively characterize samples of sunflower seeds maximum mass to form a head, forming

This work is licensed under Creative Commons Attribution 4.0 License DOI: 10.19080/ARTOAJ.2017.04.555638 eventually a maximum level yield. For samples with a mass formed by a basket of seeds within the 42.6-55.9g discharge coefficient of soil moisture per unit of net productivity of photosynthesis is in minimum values of $1.04-1.24 \mathrm{~m}^{3} / \mathrm{g} / \mathrm{m}^{2}$ per day.

Against the background created by the source material, new accessions OR42, OR171, ORE77 had a minimum flow rate of soil moisture per unit of NPP 1.04-1.05 $\mathrm{m}^{3} / \mathrm{g} / \mathrm{m}^{2}$ per day during the formation of the maximum level of productivity 2.3$.5 \mathrm{t} /$ hectare. Thus, the individual selection of sunflower plants at the molecular level by allelic variants of the components of electrophoretic spectra of seed storage proteins in the process of establishing inbred lines to evaluate and select new models, which do not differ in morphology, but have differences in allelic variants of electrophoretic spectra and are characterized by a high levels of productivity without reducing the oil content of seeds.

A method of screening sunflower samples at high efficiency, based on the record of soil water flow rate per unit of net photosynthetic efficiency in the phase of plant development budding - start the formation of the head and also on the ratio of seed weight head (SP- breeding sign) and soil water flow rate per unit net productivity of photosynthesis (OP- background sign) solves the problem of sampling at high productivity to the beginning of the flowering phase. As an index for selection of sunflower samples offered high productivity of the flow rate of soil moisture in photosynthesis per unit phase forming head.

\section{Your next submission with Juniper Publishers will reach you the below assets}

- Quality Editorial service

- Swift Peer Review

- Reprints availability

- E-prints Service

- Manuscript Podcast for convenient understanding

- Global attainment for your research

- Manuscript accessibility in different formats

( Pdf, E-pub, Full Text, Audio)

- Unceasing customer service

Track the below URL for one-step submission https://juniperpublishers.com/online-submission.php 